\title{
Computer Science Major Students' Entrepreneurship Practice Ability Training Mechanism
}

\author{
Wu Yafen ${ }^{1}$, Liu Yan ${ }^{2}$, Hu Jian guo ${ }^{3}$, Gui Wei $^{4 *}$ \\ 1,3. Research Department,Jiangxi University of Traditional Chinese Medicine, 818 Meiling Road, \\ Nanchang 330004, Jiangxi, P.R. China ; \\ 2,4. Department of Psychology, Jiangxi University of Traditional Chinese Medicine, 818 Meiling \\ Road, Nanchang 330004, Jiangxi, P.R. China ; \\ *Corresponding author: Gui Wei .Email:476131664@qq.com \\ Wu Yafen and Liu Yan are co-first authors.
}

This work has been supported by the Jiangxi Province Federation of Social Sciences and Project of Humanities and Social Sciences in Jiangxi Province.

\begin{abstract}
Keywords: Computer science major; Entrepreneurial practice ability; Training mechanism; Teaching
\end{abstract}

\begin{abstract}
Because of the demand of economic and social development, the focus of current college students' learning is to cultivate the students' entrepreneurial competence which is an important way for the students to realize their self value and getting into the society. As an emerging subject, the application scope of computer is expanding in various social aspects. It is very important to strengthen the entrepreneurial practice ability of computer major students. Through the study of computer major teaching activities in our country, find the problems existing in computer major students' entrepreneurial practice ability, and carry on research and analysis of these problems to provide effective methods and measures for computer major students' entrepreneurial practice ability training in our country. Build a perfect, rational and scientific mechanism for computer science major students' entrepreneurial practice ability training.

In recent years, the development of education enterprise in our country has entered popularization development stage. Students at this stage in our country are faced with more and more severe employment situation. Currently college students have characteristics like active thinking, strong acceptation ability and higher degree. They are a group with most entrepreneurial innovation potential. At present our country's relevant departments also provide very useful policy support for college students' entrepreneurship. An important way of college students' entrepreneurship is to strengthen the cultivation of students' entrepreneurship practice ability. But at present students' entrepreneurship practice ability training mechanism is not perfect enough and students entrepreneurial practice ability cannot meet our country's demand for innovative talents, which requires strengthening the cultivation of entrepreneurial competence of college students in China.
\end{abstract}

\section{The connotation of computer major students' entrepreneurship practice ability training}

Researchers and scholars mainly have three kinds of views about the connotation of computer major students entrepreneurship practice ability training: 1) some view computer major students entrepreneurship practice ability training the same as innovation ability training; 2) some view students' entrepreneurship practice ability training the same as entrepreneurial education; 3) part of scholars and researchers think entrepreneurship practice ability training the same as the combination of student's entrepreneurial ability and practice ability, which is a kind of teaching activity cultivating both student innovative ability and practical ability. The basic connotation of entrepreneurship practice ability training for computer major students is to cultivate students' practical ability and entrepreneurial ability, and its main carrier is practice activity and course education. The main teaching goal is to improve and develop computer major student's innovation 
practice ability and comprehensive quality. Computer major students' entrepreneurship practice ability training is to cultivate many kinds of abilities, such as ability, knowledge and consciousness based on comprehensive quality education for students' future career. Computer major students' entrepreneurial practice ability training can improve the students' entrepreneurial ability and practice ability.

\section{Problems existing in computer major students' entrepreneurial practice ability}

There are problems existing in entrepreneurial practice ability training in China which is evident by means of computer major college students' entrepreneurship research and analysis. These problems seriously affect our country's computer science major entrepreneurship practice ability training.

\section{Insufficient understanding about entrepreneurial practice ability training.}

Computer science is an innovative major emerging in our country, so most colleges and universities do not have enough teaching experience in the process of cultivating computer major students, and cannot further understand and aware the idea of computer major students entrepreneurial practice ability training. The insufficient understanding of this emerging major leads to a lot of computer major education in colleges and universities is only on the cultivation of computer professional technology and knowledge, and teaching methods and teaching means are single for computer major students. A lot of universities cannot establish a more correct view of entrepreneurship practice ability training for computer major, so they cannot build a complete, scientific and reasonable entrepreneurship practice ability training mechanism.

\section{Imperfect computer science major curriculum system set.}

Computer major students' entrepreneurship practice ability training in colleges and universities is mostly in extracurricular activities, and it is not enough and has many faults such as temporary dealing and passive [1]. Many colleges and universities often only set some employment and entrepreneurship related auxiliary courses in computer major curriculum. These courses simply provide certain assistance to students' employment in the future, and there is no link with computer science. Entrepreneurial practice is not connected with entrepreneurship ability in computer science curriculum design in colleges and universities.

\section{Inefficient entrepreneurship practice ability training level of computer major faculty.}

Research and analysis of computer major teachers in colleges and universities show that most colleges and universities lack teachers to guide computer science students' practice ability, so they lack corresponding teachers to give computer entrepreneurship guidance. Many colleges and universities computer teachers have the characteristics of high research capacity, high title and higher education, but their entrepreneurial ability and practice ability are in great shortage, leading to they cannot guide and cultivate students' computer major entrepreneurship practice ability in course teaching.

\section{Computer major specialized classroom teaching needs to be optimized.}

College and university teachers only teach computer professional skills and knowledge to computer major students, but do not pay enough attention to the cultivation of students' entrepreneurship practice ability [2]. Because computer major is emerging, a lot of teachers have no experience in this aspect of teaching, so in the classroom teaching, they still use traditional teaching methods, and students receive knowledge passively, which cannot motivate students' learning initiative and enthusiasm; And many colleges and universities computer major assessment is single and only pay attention to students' basic knowledge leaned in classroom and professional skill assessment and does not set up corresponding assessment for entrepreneurial practice ability of students.

\section{The atmosphere of computer major entrepreneurial practice is not enough.}

Computer major entrepreneurial atmosphere in our society is not enough, and the corresponding entrepreneurial environment belongs to middle level, which is not perfect enough. And computer major entrepreneurial benefit range and radiation scope are narrow. Computer major entrepreneurial activity is confined to establish corresponding work or Science and Technology Park, but because 
of factors such as capital and resources which affect computer major entrepreneurship, college graduate students majoring in computer may be kept outside the door of entrepreneurship.

\section{Build perfect mechanism for computer major students' entrepreneurial practice ability training}

Pay attention to the cultivation idea of computer major entrepreneurial practice ability.

Colleges and universities should pay much attention to computer major students' entrepreneurship practice ability training, and carry out innovation and reform according to the concept for computer major's course system, teaching content and education modes [3]. In computer major students entrepreneurial practice ability training, first transform and update education idea and education thoughts, and then have a correct understanding of the relationship between entrepreneurial practice ability and computer professional knowledge technology. Carry out reforms on traditional and single computer major teaching concept. In computer major course teaching, put the core and key of teaching on student's entrepreneurial spirit, practice ability and innovation consciousness. Constantly carry out reforms in computer major curriculum system and talent training modes. Computer teachers in colleges and universities should set up teaching ideas combining students' entrepreneurial practical ability and calculating professional education, and constantly infuse the cultivation of entrepreneurial practice competence into computer major students' courses.

\section{Strengthen the improvement of computer major curriculum system.}

Computer major students entrepreneurial practice ability training needs the fusion of entrepreneurship courses, practical courses, and professional courses to build a diversified curriculum system which complements each other for our country's college students majoring in computer. First, open some elective or required courses about computer ship entrepreneurial courses. In compulsory computer entrepreneurial course, focus on the theoretical knowledge of students' computer entrepreneurship to cultivate computer major students' entrepreneurial practice consciousness [4]. In computer entrepreneurial courses, focus on the cultivation of computer major students' entrepreneurial practice ability and personalized style. Second, computer major students' public entrepreneurship course is optimized. Colleges and universities generally have a more perfect employment entrepreneurship curriculum system. In entrepreneurial common course for computer major students, take advantage of the characteristics of computer major to cultivate the students' pioneering consciousness. Finally, integrate computer professional courses and entrepreneurship practice courses. Fuse entrepreneurship practice course in computer courses can infiltrate the elements of entrepreneurial practices to professional course and let the students form their own entrepreneurial practice ability training in learning professional courses.

\section{Strengthen the construction of teaching staff in computer engineering.}

Universities should be able to perfect their own computer major teacher selection, training and introduction mechanism and gradually build a more perfect teaching team for students' entrepreneurial practice ability. Firstly, we should strengthen computer education talents introducing, and colleges and universities also should cooperate with related computer companies. Universities which are qualified also should deliberately invite some computer entrepreneurs to school to give computer entrepreneurial course for computer students [5]. Secondly, schools should organize professional teachers to participate in computer entrepreneurial practice training. Let computer professional teachers master the basic knowledge of entrepreneurial practices, as well as organize teachers' participation in computer industry research, update the knowledge structure of teachers, and make teachers a more comprehensive grasp of computer industry's dynamic development and results.

Improve the environment of computer major entrepreneurial practice ability training.

First of all, improve computer entrepreneurial environment of market economy in our country, and relevant government departments should integrate resources, provide funds and mechanism encouragement for computer major student entrepreneurship. Computer major students' threshold of venture capital is reduced. Corresponding entrepreneurial training are provided to computer 
major students and strengthen the construction of computer science and technology entrepreneurial park. At the same time let computer entrepreneurs step into the campus and let these entrepreneurs' success stories arouse the enthusiasm of students' entrepreneurship practice ability training. Second, colleges and universities can provide computer major students a good entrepreneurial environment and atmosphere, constantly organize a variety of entrepreneurial lectures, entrepreneurial practice competition and campus entrepreneurship practice activities. This would mobilize students' selfemployed practice ability and let the students actively get into the cultivation of entrepreneurship practice ability.

\section{Conclusion}

The source and motivation of a nation's economy and industry development is entrepreneurial activity. Through the analysis of computer major students' entrepreneurship practice ability training mechanism, this paper finds out the current problems existing in entrepreneurial practice ability training to improve our country's computer major students entrepreneurial practice ability training mechanism. This not only can improve the students' entrepreneurship and practice ability, and adaptability of the market economy, but also has a very important role in the development of our country's computer industry.

\section{References}

[1] Du Juan, Teng Yanping, Jin Mei. University computer professional practice innovative undertaking teaching reform [J]. Journal of College of Science, 2015, (9) : 87-89.

[2] Liu Liqun. Setting up three-dimensional practice teaching system of students' innovative entrepreneurial ability cultivating [J]. Journal of Education and Profession, 2013, (32) : 164-165.

[3] Li Ying. College computer professional students' innovative entrepreneurial ability cultivating exploration and practice [J]. Journal of Electronic Testing, 2016, (5) : 134-135.

[4] Lin Jian. Computer teaching mode based on entrepreneurial skills [J]. Journal of Guangdong Education (Duty Version), 2016, (4) : 89-90.

[5] Shao Qifeng, Han Yumin, Che Zhanbin. Practical ability training mode study based on college students' innovative undertaking center [J]. Journal of Computer Age, 2015, (9) : 71-74. 